\title{
MACROECONOMIC POLICY IN THE PRESENCE OF STRUCTURAL MALADJUSTMENT
}

Robert J. Gordon

Working Paper 5739

\section{NATIONAL BUREAU OF ECONOMIC RESEARCH 1050 Massachusetts Avenue \\ Cambridge, MA 02138 \\ September 1996}

This research has been supported by the National Science Foundation. I am grateful to Martin Cohan and Tomonori Ishikawa for help with the data and graphs. This paper is part of NBER's research program in Economic Fluctuations and Growth. Any opinions expressed are those of the author and not those of the National Bureau of Economic Research.

(C) 1996 by Robert J. Gordon. All rights reserved. Short sections of text, not to exceed two paragraphs, may be quoted without explicit permission provided that full credit, including (C) notice, is given to the source. 


\title{
MACROECONOMIC POLICY IN THE \\ PRESENCE OF STRUCTURAL \\ MALADJUSTMENT
}

\begin{abstract}
This paper analyzes two-way interactions between structural reform and macro policy. If structural reforms increase the flexibility of labor markets, they are likely to improve the short-run inflation-unemployment tradeoff, providing an incentive for policymakers to expand aggregate demand. In turn, the promise by policymakers that they will encourage a decline in unemployment in response to good news on inflation can be used to strike a political deal with political interests opposed to the introduction or extension of structural reform. Expansionary monetary policy also provides relief on the fiscal front, directly by bringing the actual budget deficit closer to the structural budget deficit, and indirectly, by encouraging structural reform, potentially reducing the structural budget deficit itself.

In 1992-93 several European countries dropped out of the ERM to pursue more expansionary monetary policies. The difference in the performance of these countries and those countries which maintained a peg between their currencies and the Deutsche mark provides an important test case of the consequences of expansionary monetary policy. The depreciating nations by 1995 enjoyed a substantial relative acceleration of nominal GDP and, surprisingly, an even greater deceleration of inflation, so that their growth rate of real GDP accelerated more than their growth rate of nominal GDP in relation to the pegging countries. The continued deceleration of inflation in the depreciating countries provides evidence that their natural unemployment rate has declined and that expansionary monetary policy has interacted beneficially with structural reform.
\end{abstract}

\section{Robert J. Gordon}

Department of Economics

Northwestern University

Evanston, IL 60208

and NBER

rjg@merle.acns.nwu.edu 


\section{Introduction}

Perhaps the most important single economic issue in Europe today can be linked to the topic of this paper, macroeconomic policy and structural maladjustment. Is it possible for Europe to pursue the macroeconomic policies needed to achieve monetary union despite the existence of structural maladjustments, such as excessive fiscal debt and deficits, underfunded state pension and welfare programs, state subsidies of inefficient firms, and overregulated product and labor markets? What are the connections and feedbacks between macro policy and structural reform? Do these connections suggest any new avenues for policy in countries like France that are currently struggling to resolve the conflicts among fiscal stringency required on the route to monetary union, monetary tightness required to maintain a fixed exchange rate, and the political strife with interest groups resisting structural reform?

The paper begins by examining data on major aspects of macroeconomic performance in Europe and the United States. It then turns to a theoretical section that interprets the interactions between macro policy and structural maladjustment in terms of aggregate demand and supply analysis. In this view, the task of macro policy is to control the growth rate of nominal aggregate demand, while structural maladjustment can be viewed as an adverse supply shock, and successful structural reform as a beneficial supply shock. We shall analyze the similarities and differences between the effects of structural maladjustment and adverse supply shocks, such as oil price shocks. 
The supply shock model forces us to distinguish between the level and rate of change of structural maladjustment. Structural reform may be viewed as analogous to a negative change in the degree of structural maladjustment. On closer examination some types of structural reform are just as likely to reduce the rate of productivity growth as to raise it. The analysis of demand and supply shocks forces us to distinguish as well between two leading models of aggregate supply - the natural rate hypothesis and the hysteresis model - and a hybrid that combines them. How does the outcome of alternative policy interventions depend on knowing the right model in advance?

The next section of the paper examines feedback from reform to macro policy: countries with more flexible markets may have a more favorable short-term inflationunemployment tradeoff. This is particularly important from the perspective of the hysteresis hypothesis, which implies that a reduction in unemployment may be achieved at the cost of only a finite increase in the inflation rate, the amount of which depends on the slope of the short-run tradeoff curve. There is also feedback from macro policy to reform: a policy that leans in the direction of expansion may make it possible to create a political deal with interest groups that resist reform. An expansionary policy also reduces the impact of transition costs from reform.

Most of our discussion of macro policy revolves around monetary policy and exchange rate policy. There is still the need to determine where fiscal policy fits in. 
Is there still a role for fiscal policy in managing aggregate demand? The theory of the monetary-fiscal mix states that monetary policy mainly controls aggregate demand; fiscal policy mainly influences the real interest rate and hence the rate of long-run capital accumulation and growth.

Should monetary policy be conducted differently in nations that have relatively high ratios of public debt to GDP? When fiscal deficits exceed the level consistent with a stable debt-GDP ratio, the need to run a budget surplus becomes an imperative and requires a stimulative monetary policy to compensate, with the implication that exchange rate stability may not be consistent with fiscal convergence.

The empirical section of the paper examines data on the experience of selected European countries since the 1992 breakdown of ERM, which provides a controlled experiment of the consequences of expansionary aggregate demand policy. We examine the behavior of nominal GDP growth, as well as the "split" of nominal GDP growth between inflation and real GDP growth, in those countries that experienced major effective exchange rate depreciations in 1992-93 as compared with some of those that did not depreciate. We conclude by developing the implications of the empirical results for future macro policy within Europe and exploring the desirability of a continued push toward monetary union. 


\section{The Primary Puzzles in Macrooconomic Behavior}

\subsection{Inflation, Unemployment, and Labor's Share}

We begin by comparing basic macroeconomic indicators for Europe and the United States, in order to identify the puzzles to be explained. Figure 1 displays the well-known divergence in the time series of unemployment rates in Europe and the United States. In 1995 the unemployment rate for the current members of the European Union (labelled "Europe" in Figure 1) was 11.0 percent, compared to roughly 2 percent for the same countries in the early 1960s. The 1995 unemployment rate in the United States was 5.7 percent, exactly the same as in 1963. The upsurge of European unemployment relative to U.S. unemployment occurred primarily between 1975 and 1985, suggesting that the search for an explanation should begin with major structural changes that occurred within Europe during that decade.

The major theories that describe the interrelation between the unemployment and inflation rates are the natural rate hypothesis and the hysteresis hypothesis. Inflation rates for the United States and the same set of European countries are displayed in Figure 2. Here we see that the average inflation behavior of "Europe" has been remarkably similar to that of the United States since the late 1960 s, with the European inflation rate exceeding that for the United States by one or two percentage points per year in most years. Given the similarity of the inflation performances, the 
natural rate hypothesis is consistent with the data only if the natural rate of unemployment was roughly stationary in the United States over the last three decades but increased by roughly as much as the actual unemployment rate in Europe over the same period. This leaves the causes of the increase in the European natural unemployment rate unexplained.

During the early 1980 s a popular explanation for the divergence of European and U. S. unemployment rates was a contrast in labor-market behavior. The seminal work of Branson-Rotemberg (1980), Sachs (1979), and Bruno-Sachs (1985), emphasized the contrast between real wage rigidity in Europe and real wage flexibility in the U. S. Following the early-1970s slowdown of productivity growth shared in common by all industrialized nations, real wage flexibility in the U. S. allowed the growth of real wages to decelerate in tandem with productivity growth, while real wage rigidity in Europe prevented such a deceleration.

It is easy to assess the validity of this hypothesis by examining data on labor's share in national income. By definition, labor's income share $(S)$ is equal to the real wage $(W / P)$ divided by output per hour $(Q / H)$. Using lower-case letters for logs, this definition implies that the growth rate of the real wage is equal to the growth rate of productivity plus the growth rate of labor's share:

$$
\Delta w-\Delta p=(\Delta q-\Delta h)+\Delta s
$$


Thus any tendency of the growth rate of real wages $(\Delta w-\Delta p)$ to exceed the growth rate of productivity $(\Delta q-\Delta h)$ would be reflected in positive growth in labor's share $(\Delta s)$. In consequence, the real-wage rigidity hypothesis leads us to expect that labor's share in Europe would have increased relative to that in the United States during 1975-85, the period of the rising relative European unemployment rate. As the cost of labor increased relative to its marginal product, profits would have been squeezed, the demand for labor would have decreased, and unemployment would have increased.

The real-wage rigidity hypothesis regarding Europe has as its counterpart a substantial U.S. literature on the failure of real wages to grow over the past two decades, despite a positive (albeit small) growth rate of output per hour. In the American view, structural features of U. S. labor markets account for the failure of real wages to keep pace with productivity. According to equation (1), this common perception implies that the U.S. wage share must have declined substantially. For zero real wage growth to have been consistent with a 1.0 percent annual rate of productivity growth, labor's share should have declined at 1.0 percent per year, for instance from 70 percent in 1973 to 53 percent in 1993.

Both the real-wage rigidity hypothesis for Europe as well as the common U. S. perception of stagnant real wages appear to be the reverse of the truth, as shown by the display of wage shares in Figure 3. These wage share series, constructed by the 
OECD, include in wage income an imputation for the labor income earned by the self-employed. Far from declining rapidly, the wage share series for North America (dominated by the U. S. ) has remained roughly constant, falling only from 68 percent in 1973 to 66.5 percent in 1993 . The wage share series for Europe did increase relative to North America during 1974-81, which coincides with the period when the European unemployment rate began its relentless descent. But since 1981 the European wage share has declined much more, from a 1981 value of 69.3 percent to 63.4 percent in 1993.

Thus any effect on unemployment of the high European wage share during the late 1970 s should have been more than reversed by the declining wage share during the 1980 s and early 1990 s. The absence of such a reversal in the natural unemployment rate casts doubt on the original rigid-real-wage hypothesis as a convincing cause of persistently high European unemployment. The difficulty in this explanation is parallel to that in linking the worldwide post-1973 productivity slowdown in the industrialized countries to the oil price shocks of the 1970 s, since the oil shocks have now been completely reversed in real terms, while the productivity slowdown has not been reversed in most countries.

Competing with the view that the increased natural rate of unemployment was structural in origin is the hysteresis hypothesis, which postulates that the natural rate is "state dependent," automatically following in the path of the actual unemployment 
rate like the tail of a dog. ${ }^{1}$ The hysteresis hypothesis can explain the evolution of actual unemployment in Europe by a combination of events that raised the actual unemployment rate, especially adverse supply shocks (e.g., higher oil prices and a temporary increase in labor's share) accompanied by restrictive demand policy. In turn, through hysteresis the natural rate followed in the path of the actual unemployment rate. Because the actual unemployment rate was above the natural rate during the transition process, the inflation rate declined, as shown in Figure 2. To reverse the process, some combination of beneficial supply shocks supported by expansionary demand policy must bring the actual unemployment rate below the natural rate, i.e., the unemployment gap must become negative, in order to "drag down" the natural rate.

As we shall see in Figdre 4, none of the major European countries is close to having a negative unemplcyment gap. The consequence of such hypothetical expansionary policies would be to raise the inflation rate until the economy stabilizes at a new equilibrium with a lower actual and natural unemployment rate, and a more rapid rate of inflation. A key issue in evaluating the merits of expansionary policy is to determine the tradeoff between inflation and unemployment in the transition to the new equilibrium. The divergent experiences of those countries that dropped out of the ERM in 1992-93 highlight the recent behavior of the tradeoff.

1. See the recent book edited by Cross (1995a), especially his own essay (Cross, 1995b). 
Macroeconomic Policy, Page 9

\subsection{Unemployment Gaps, Structural Deficits, and the Stabilizing Deficit Ratio}

Studies are available for many different countries which provide estimates of the natural rate of unemployment, and of the gap between the actual and natural rates of unemployment. 1995 unemployment gaps for the G-7 countries, plus Spain and Sweden, are shown in Figure 4. The source is Giorno et. al. (1995), which uses a method developed by Elmeskov and MacFarlan (1993). The natural rate of unemployment is estimated by solving an equation in which the rate of change of wages is related simply to the unemployment gap; thus the natural unemployment rate is equal to the actual unemployment rate in any year in which wages are neither accelerating nor decelerating. The unemployment gaps in Figure 4 are arrayed between the United States, which in 1995 had a negative unemployment gap and was assessed to be producing actual real GDP in excess of potential real GDP, and the other extreme France and Spain, with estimated unemployment gaps in excess of 3 percent. The average gap for Europe is about 2 percent, and subtracting this from the actual unemployment rate of 11 percent (Figure 1) implies that the natural unemployment rate for Europe in 1995 was about 9 percent, much higher than the estimate of 6 percent for the United States. ${ }^{2}$

2. In Gordon (1995a) I have recently estimated the U. S. natural rate of unemployment as a timevarying parameter and have found it to have decreased gradually from about 6.4 percent in 1981 to about 5.8 percent in 1995. 
Using a version of Okun's law to translate unemployment gaps into gaps between actual and potential output, Giorno et. al. (1995) also compute structural budget deficits, i.e., the budget deficit that would be incurred if the economy was operating at potential output instead of at actual output. Figure 5 displays the 1995 estimates for the same set of countries covered by Figure 4 and shows that most of the fiscal problems of the high-deficit European countries are structural rather than recession-induced. None of the European countries have actual deficits that are more than double their structural deficits. Of course, if the natural rate of unemployment were lower in these countries, the structural deficits would be correspondingly lower. This provides a link between the hysteresis hypothesis and the fiscal dilemma facing Europe. There is the possibility that monetary expansion could pull down both the actual and natural rates of unemployment, and thus reduce the structural deficits without politically difficult budget-cutting. But this would require exchange rate depreciation, the acceptance of additional inflation, and the abandonment of monetary union.

The consequence of large fiscal deficits is, of course, an increase in the ratio of government debt to GDP. Currently for the major European countries this ratio ranges from 52 percent for France to 125 percent for Italy, as shown in Figure 6 . A standard relation states that stability of the debt-GDP ratio requires that the deficitGDP ratio be equal to the growth rate of nominal GDP times the debt-GDP ratio. 
Table 1 compares the actual and structural deficits for the same countries included in Figure 6 with a computed "stability value" of the deficit-GDP ratio. The stability ratio is the current debt-GDP ratio from Figure 6, multiplied by the "warranted" growth rate of nominal GDP, which in turn is set equal to the rate of potential output growth plus the current rate of inflation. ${ }^{3}$ As shown in the first column of Table 1, for the U. S., in which nominal GDP growth of 5.0 percent is consistent with steady inflation and steady output growth at the potential rate, the required deficit-GDP ratio is 2.3 percent (.46 times .05 equals .023 ), a bit above the 1995 actual deficit and exactly equal to the 1995 structural deficit. Hence the figure displayed on line 5 for the U. S. is -0.5 , indicating that the actual deficit is smaller than the stability value, implying a slight shrinkage in 1995 of the debt/GDP ratio, while the figure displayed on line 7 is 0.0 , indicating that the structural deficit is exactly equal to the stability value.

Table 1 includes similar calculations for the other European countries covered by Figures 4-6. Line 5 shows that all but Germany and Italy have actual deficits well in excess of the stability value, implying continued growth in the debt-GDP ratio. The surprising inclusion of Italy in the stability group results from a combination of a huge debt/GDP ratio and relatively rapid inflation (and hence high warranted

\footnotetext{
3. For countries with positive unemployment gaps in Figure 4, the natural rate hypothesis predicts that inflation is decelerating. Thus the warranted nominal GDP growth rate allows the rate of real GDP growth to accelerate pari passu with the deceleration of inflation until the unemployment gap is eliminated.
} 
nominal GDP growth). The list of countries with structural deficits in excess of the stability value on line 7 is the same as the list of countries with positive gaps on line 5 , although of course the debt/GDP ratio would grow more slowly if these countries adopted expansionary policies to eliminate their output and unemployment gaps.

\subsection{Exchange Rates, Demand Growth, and Inflation}

The macroeconomic policy discussion within Europe over the past few years has been dominated by the Maastricht conditions for monetary union, and the debate over the significance of the breakdown of the ERM in 1992. Figure 7 plots the effective exchange rates of the four largest European countries from 1981 to 1995 . The history has three stages: convergence from 1981 to 1987, the ERM period from 1987 to 1992, and then the breakdown period starting in 1992.

Subsequently we will return to the recent period and ask how the post-1992 divergence of exchange rates influenced nominal GDP growth and the split of nominal GDP growth between real GDP growth and inflation. A preview for the four largest countries is provided in Figures 8 and 9. Many different factors influence nominal GDP growth, and we can focus on several major episodes. The major events that occurred after 1987 were the British boom of 1987-89, the German reunification boom of 1990-91, and the divergence of British nominal demand growth from the French rate after 1992. Italy presents a puzzle, with the appearance 
of convergence of nominal GDP growth closer to the French rate rather than divergence after the 1992 Italian exchange rate depreciation.

Further puzzles are evident in the behavior of inflation rates in Figure 9. French and German inflation rates were relatively close together after 1987, except for the period of the German reunification and its aftermath, 1991-93. The puzzle is that British and Italian inflation rates were much closer to the French and German inflation rates after 1992 than before. We shall return to this puzzle, and its implications for demand management policy, in section $\mathrm{V}$ of the paper.

\section{Structural Maladjustment and Aggregate Demand-Supply Analysis}

This section links the two main topics of the paper, macro policy and structural maladjustment, to several simple analytical tools and theories. These include the distinction between demand and supply shocks, the natural rate hypothesis, the hysteresis hypothesis, and the response of demand-management policy to supply shocks.

\subsection{Demand Shocks and the Natural Rate Hypothesis}

We begin with the familiar expectational Phillips curve diagram in Figure 10, which plots the inflation rate against the unemployment rate. If the natural rate hypothesis is valid, the long-run Phillips curve (LP) is a vertical line rising above the natural unemployment rate $\left(U^{*}\right)$. The initial short-run Phillips curve $\left(S P_{\curlywedge}\right)$ is drawn 
on the assumption that the expected inflation rate is $p_{0}^{e}$ which in turn is equal to the actual inflation rate $\left(p_{a}\right)$, the point in the vertical dimension at which the $S P$ curve intersects the vertical $L P$ line. The $S P$ curve shifts whenever there is a change in the expected inflation rate $\left(p^{e}\right)$. The SP curve can also shift upward in the case of an adverse supply shock, and down in the case of a beneficial supply shock. We will shortly link the concept of structural maladjustment to that of supply shocks.

The influence of aggregate demand is shown by the DG (for Demand Growth) schedule. The position of the DG schedule is determined by the excess of the rate of nominal GDP growth over potential output growth, or "excess nominal GDP growth" $(x)$, as well as the previous period's unemployment rate. When $x$ is equal to the inflation rate, then by definition actual output growth is equal to potential output growth, and the unemployment rate is fixed. When $x$ exceeds the inflation rate, then actual output growth exceeds potential output growth, and the unemployment rate declines. ${ }^{4}$

Consider the effect of a permanent acceleration of excess nominal GDP growth from $x_{0}$ to $x_{1}$. The $D G$ line shifts upward as shown, and the economy initially moves to point $E_{1}$. With adaptive expectations and an adjustment coefficient of unity, the

4. When this analysis is done on a diagram with the output gap on the horizontal axis, then the $D G$ schedule is a negative 45 degree line. If the Okun's law coefficient linking the unemployment gap to the output gap were unity, then the DG schedule in Figure 10 would be a positive 45 degree line. If the Okun's law coefficient is 2 (an output gap of 2 corresponds to an unemployment gap of 1), then the slope of the DG line is 2 , indicating that a shortfall of inflation below $x$ of one percentage point corresponds to an unemployment gap of minus 0.5 . 
expected inflation rate is equal to last period's actual inflation rate. Hence in the subsequent period the $S P$ line shifts upward to cross the $L P$ line at a point (marked C) directly to the right of point $E_{1}$. In the subsequent period the $D G$ schedule shifts to intersect the long-run rate of inflation directly above the initial equilibrium point (at the point marked $A$ ). ${ }^{5}$ If the rate of excess nominal GDP growth is maintained at $x_{1}$ permanently, the economy will go through the loop shown by the dashed spiral line.

This diagram summarizes the basic results implied by the natural rate hypothesis. A permanent acceleration of excess nominal GDP growth causes a permanent acceleration of inflation of the same amount after a transition period in which the inflation rate oscillates above and below its long-run equilibrium value. Maintaining an unemployment rate $\left(U_{\nu}\right)$ below the natural unemployment rate $\left(U^{*}\right)$ requires a steady acceleration of excess nominal GDP growth and results in a steady acceleration of the inflation rate. The process is symmetric if the short-run Phillips curve is linear, as shown in Figure 10. A deceleration of inflation requires a permanent deceleration of excess nominal GDP growth, results in oscillating inflation, and a temporary period of unemployment above the natural rate.

5. Imagine a $D G_{2}$ line drawn through point $A$. This indicates that the unemployment rate would be unchanged if the inflation rate at that point $\left(p_{2}\right)$ equalled the value of excess nominal GDP growth $\left(x_{1}\right)$ at the same point. 


\subsection{Supply Shocks and the Interpretation of Structural Maladjustment}

Figure 11 uses the same model to examine the effects of an adverse supply shock. The shock is viewed as shifting the $S P$ schedule upwards without changing its slope. If the shock is an agricultural crop failure, the relative price of farm products will temporarily increase, and the initial $S P_{0}$ schedule will shift upward to $S P^{\prime}$. But after the cause of the agricultural problem is over and normal conditions return, the relative price of farm products will decline. The economy will temporarily enjoy a beneficial supply shock due to the relative price decline, and the SP curve will shift down to SP" during the transition period back to normal prices. The OPEC oil shocks of 1974-75 and 1979-81 raised the relative price of oil for a substantial period. In this case the upward shift of the $S P$ curve to $S P$ ' is followed by a return to the initial position $\left(S P_{0}\right)$ when the transition to the higher relative price is complete, ignoring the impact of shifting inflation expectations.

A central case useful for the analysis of supply shocks is a situation in which excess nominal GDP growth remains unchanged at $x_{0}$, and so for the initial transition period the DG schedule remains fixed. Then with an adverse supply shock the economy would go initially to point $L$, with higher inflation and higher unemployment. Even if in the subsequent period the supply shock goes away, the SP schedule will stay above its initial position if expectations are formed as we assumed previously in Figure 10, reflecting the response of expected inflation to the higher 
actual inflation caused by the supply shock. Gradually higher unemployment will push down the inflation rate, and the economy will slide back to the initial position by the route shown by the dashed line.

But policymakers will be tempted to fight the unemployment caused by the supply shock. If they accelerate nominal demand growth sufficiently, i.e., pursue a policy of "accommodating" the supply shock, the economy will avoid an increase in unemployment but at the cost of a permanent increase in inflation. The economy will arrive at a point like $\mathrm{N}$, with both actual and expected inflation equal to the permanently higher rate of excess nominal GDP growth. The shift from a point like $E_{0}$ to a point like $N$ provides a realistic description of the process by which the U. S. made a transition from 5 percent inflation in the early 1970 s to 10 percent inflation in the late 1970 s.

The opposite extreme is a policy of "extinguishing" the supply shock. Nominal GDP growth is dropped sufficiently to push the economy rightward to a point like M. Because inflation does not accelerate, there is no adjustment of expectations. Eventually, when the initial transition is completed (i.e., the relative price of oil settles down to its new higher level), the SP curve will shift back to its initial position. However, excess nominal GDP growth has been diminished, and if this reduction is maintained, there will be a permanent reduction in the rate of inflation in the subsequent transition. In short the policymakers face a tradeoff in reacting to supply 
shocks, with a neutral (point $L$ ) or extinguishing (point $M$ ) policy implying a temporary increase in unemployment, but an accommodating policy (point $N$ ) implying a permanent increase of inflation. The contrast between the effects of accommodating and extinguishing policies helps to explain why Germany did not experience an increase in its inflation rate in the late 1970s, whereas the U. S. and several other European countries did experience an acceleration of inflation that persisted until the major monetary restriction of the early 1980 s began.

Numerous events can be fit into the framework of supply shocks and demand responses. In particular, Franz-Gordon (1992) show that a change in labor's share, such as that implied by the real-wage rigidity hypothesis discussed in Part II, shifts the inflation-unemployment relation in exactly the same way as a change in the relative price of oil. The SP schedule shifts upward during the period when labor's share is increasing. Whether or not it returns to its original position depends on the degree of accommodation, if any, and the adjustment of expectations of inflation.

Thus far the analysis does not allow for a permanent increase in unemployment, simply because the natural rate hypothesis is maintained and we have not allowed for an increase in the natural rate of unemployment. This could occur in two ways. First, the nature of the structural maladjustment could be to impair the functioning of the labor market sufficiently to increase the natural rate. Second, there could be a hysteresis mechanism in place which automatically translates a 
period of high actual unemployment into an increase in the natural rate of unemployment.

Krugman (1994) asks whether generous European welfare policies, combined with a relatively high reservation wage (or legal minimum wage) could explain the rise in the natural unemployment rate in Europe. Such policies could explain high unemployment but not rising unemployment, as was observed between the early 1970s and late 1980s, unless the benefits had increased significantly. But European welfare states were already generous back in the early 1970 s when unemployment was relatively low. Instead, he argues that the facts are consistent with a twist in the demand for labor, combining a decrease in the demand for low-productivity workers and an increase in the demand for high productivity workers. If reservation wages do not change, or if there is a minimum wage that does not change, then the decreased demand for low-productivity workers will be translated into higher unemployment rate than reduced relative wages. This hypothesis is consistent with the facts that long-term unemployment of young people has increased significantly in many European countries, while in the United States the same demand twist has emerged in the form of an increase in the inequality of wage rates. In searching for explanations of the demand twist, Krugman rejects international competition from low-wage countries, which he argues would change the sectoral mix of high skill 
relative to low skill employment. Instead, he favors the explanation that there has been a generalized skill-biased shift in technology that has affected all industries.

Krugman places his emphasis on skill-biased technology shifts by comparing the evolution of European and American labor markets. In contrast, Bean (1994) argues that no one factor appears significant enough fully to explain the increase in European unemployment and concludes that there must be multiple causes, rather than a single cause. Gordon (1995), like Krugman, uses the differing performance of the American and European economies as a criterion to assess the plausibility of a long list of potential causes of a rising natural unemployment rate in Europe in contrast to a stable (and recently declining) natural rate in the United States. He centers his analysis on a standard labor market diagram in which, following Layard et. al. (1991), short-term equilibrium occurs at the intersection of a labor demand curve with a positively sloped "wage setting curve" which displays the wage that emerges from the bargaining process at alternative levels of labor input. What factors could have caused the European wage-setting curve to shift upwards or the U. S. wage-setting curve to shift downwards?

1. An increase in the tax wedge. Since firms pay pre-tax wages but workers receive after-tax wages, any increase in payroll or income taxes can shift up the wagesetting schedule. The tax wedge in the Europe is both higher and increased more than in the United States between the late 1960s and late 1980s (Bean, 1994, p. 586). 
2. The rigid real wage hypothesis seems consistent with the observed bulge in the European labor share between 1974 and 1982 (Figure 3 above), which coincides with the period of most rapid increase in the natural rate of unemployment.

3. A leading candidate for causing divergent behavior across the Atlantic is the marked decline in U. S. trade union membership, from 26.2 percent in 1977 to 15.8 percent in 1993 (union members as a fraction of wage and salary workers).

4. The real minimum wage has fallen sharply in the United States while rising in some European countries, particularly France.

5. Both legal and illegal immigration of unskilled workers into the U. S. has added substantially to the supply of unskilled labor and plausibly added to downward pressure on the U. S. wage-setting schedule.

6. Product market regulation in Europe, particularly German shop-closing hours, reduce the demand fo: unskilled labor as contrasted to the demand that would emerge with an unregulated product market.

These six factors are complementary to Krugman's skill-biased demand twist and provide a convincing set of microeconomic phenomena that can be summarized by the phrase "structural maladjustment." We will return below to the interactions of structural maladjustment and reform with demand management policy and with the evolution of productivity growth. 


\subsection{The Hysteresis Hypothesis}

The second approach to explaining a permanent rise in the natural rate of unemployment is the hysteresis hypothesis. It can be shown formally that the hysteresis hypothesis is equivalent to replacing the level of the unemployment gap as the driving variable in the inflation equation by the change of the unemployment rate. ${ }^{6}$ It contradicts the basic implication of the natural rate hypothesis that demandmanagement policy cannot permanently alter the unemployment rate. Instead, it revives the original Phillips tradeoff between inflation and unemployment. A demand-induced recession boosts unemployment, which in turn boosts the natural rate. Inflation stabilizes at a new lower level when the new higher natural rate converges to the new higher actual unemployment rate. In reverse, the hypothesis implies that demand-management policy always is faced with the choice of achieving a reduction of unemployment at the cost of a finite, not ever-accelerating, increase in the inflation rate. But, unlike the original stable Phillips tradeoff, the tradeoff schedule available to policymakers at any given time depends on all of past history. The experience of high unemployment implies that European policymakers cannot push the unemployment rate as low as they could were they taking the same policy actions as fifteen or twenty-five years ago.

6. Our discussion here refers to a "linear" version of the hysteresis hypothesis in which the equilibrium unemployment rate "like an elephant" remembers all past shocks. Cross (1995b, p. 190) distinguishes this from the nonlinear version in which the memory of past shocks is selective. 
If hysteresis is present in fact, this calls for a theoretical explanation. ${ }^{7}$ The insider-outsider model of wage determination shows how employed insiders are able to convert a favorable demand or supply shock into wage increases for themselves rather than into new jobs for the unemployed. The target real-wage bargaining model goes in the same direction. In addition to total unemployment in the Phillips curve approach, nominal wage increases are influenced in addition by the deviation of real wages or of labor's income share from target levels. If the target level of labor's share responds hysteresis-like to its actual level, then any pressure on wages stemming from deviations of the actual share from the target share gradually disappears.

\subsection{Implications of Structural Maladjustment and Hysteresis}

How can the structural maladjustment and hysteresis hypotheses be interpreted in the diagrammatic framework previously introduced? In Figure 12 we consider a possibility that might have occurred in the 1970 s and early 1980 s, the conjunction of a temporary adverse supply shock caused by higher oil prices and/or an increase in labor's income share, with a permanent increase in the natural rate of unemployment caused by Krugman's labor demand twist toward more highly skilled workers, together with some combination of my previous list of supply-side 
impediments, including an increase in the real minimum wage and an increase in the tax wedge. In Figure 12 the temporary shock is indicated by the upward shift in the $S P$ curve, and the permanent increase in the natural rate by the rightward shift in the LP line.

What choices are open to policymakers? If the growth rate of nominal GDP relative to potential output growth $(x)$ remains unchanged, the economy initially moves to point $L$, just as in Figure 11 . Once the source of the supply shock is removed (e.g., the relative price of oil or labor's share stabilizes at a new level), in Figure 11 inflation and unemployment returned to their original levels. But in Figure 12 there no longer is a positive unemployment gap at point L. Inflation is higher than excess nominal GDP growth, and so output must grow more slowly than potential output, and the unemployment rate must rise relative to the new higher natural rate. The economy goes through the disinflationary loop shown by the dashed line in Figure 12, initially experiencing a further rise in unemployment and then a partial recovery to the equilibrium level $U_{1}^{*}$.

Both the structural maladjustment approach and the hysteresis approach can explain the observed increase in Europe's natural rate of unemployment. Can they be distinguished? One apprcach is to estimate wage and price equations to determine the validity of the condition for "pure hysteresis," namely the absence of a "level" effect of the unemployment gap. In one such attempt, Franz and Gordon (1992) 
found that hysteresis was partial rather than full in both Germany and the United States, since both level and rate of change effects are highly significant in both countries. Because the German and U. S. coefficients are so similar, yet the evolution of unemployment in the two countries is so different, there appears to be little potential through this route for explaining that evolution. If hysteresis is partial (i.e., inflation depends on both the level and change of the unemployment gap), it provides no explanation of a permanent increase in unemployment, since the equilibrium properties of the economy are the same as with a straightforward natural rate model in which inflation depends only on the level of the unemployment gap.

The structural maladjustment approach as depicted in Figure 12 has the appeal of realism. Oil shocks, an increase in labor's share, and a skill-biased demand twist, all began to occur in the 1970s. By the time the oil shocks and the increase in labor's share had been reversed, the natural rate of unemployment had been increased by aspects of the European welfare system that prevented the demand twist from being translated into greater inequality of wages, as it was in the United States and to some extent in the United Kingdom. 


\section{Interactions between Macro Policy and Structural Maladjustment}

\subsection{Responses of Demand Management to Successful Structural Reform}

We can now discuss interactions between structural reform and macro demandmanagement policy. If the sources of structural maladjustment are identified and microeconomic policy reform begins to reverse their effects, how should demand management policy respond? ${ }^{8}$ Our previous framework is easiest to interpret if, as in Figure 13, we assume that successful structural reform instantaneously shifts the $L P$ line leftward. We have relabeled the points on the diagram, so that the economy's initial high level of the natural rate is at $U_{0}{ }^{*}$ and moves leftward suddenly to $U_{1}^{*}$. Because the unemployment gap is now zero at point $E_{1}$ there is a new $S P_{1}$ schedule that has shifted to the left at the initial inflation rate and expected inflation rate. However, the econom!' does not move instantly from point $E_{0}$ to $E_{1}$. Instead, it moves to point $A$, which is at the intersection of the new $S P_{1}$ line with the initial $D G_{0}$ line, which holds fixed the initial rate of excess nominal GDP growth $\left(x_{0}\right)$. At point $A$ inflation has declined below the initial value of $x$, and this allows actual output growth to rise above the rate of potential output growth. Successive periods in which inflation remains below $x_{0}$ allow a temporary acceleration of output growth, which in turn allows the actial unemployment rate to decline to the new equilibrium point $E_{1}$. An alternative poiicy could achieve the same output path by temporarily

8. A detailed evaluation and chronology of structural reform efforts is provided in OECD (1994b). 
raising excess nominal GDP growth by enough to maintain a constant inflation rate, thus allowing the economy to move straight left from $E_{0}$ to $E_{1}$ rather than following the curved dashed path drawn through point A.

How can such a policy procedure be carried out in practice? The U. S. Federal Reserve Board appears to follow a policy procedure that could be interpreted as targeting the unemployment rate consistent with steady nonaccelerating inflation, i.e., adjusting interest rates to keep the actual unemployment rate as close as possible to the natural unemployment rate $\left(U^{*}\right)$. Since the Fed believes that the effects of its immediate instrument, the Federal Funds rate, take roughly one year to influence the unemployment rate, it leans toward raising the Federal Funds rate when its best forecast of the actual unemployment rate one year from now is below its estimated value of $U^{*}$. Symmetrically, it leans toward reducing the Federal Funds rate when its best forecast of the actual unemployment rate one year from now is above its estimated value of $U^{*}$.

Although $U^{*}$ may not move around as much as the actual unemployment rate, but it is not immutably carved in stone as a single precise number. When inflation turns out to be lower than the value forecast by the Fed's staff or a consensus of private forecasters, as in much of 1995 , the Fed concludes that $U^{*}$ has declined from the value previously assumed by forecasters. This makes it more likely that the Fed will reduce interest rates and less likely that it will raise them. Accordingly, a low 
realized value of inflation or a high realized value of unemployment can both lead to lower long-term interest rates as speculators guess that the Fed's next move will be to reduce short-term interest rates.

The Fed appears to act as if it is operating in a closed eçonomy environment, and it does not appear to adjust its operation of this policy procedure in response to movements of the exchange rate of the dollar. It would therefore appear that an attempt by an individual central bank within Europe to emulate the Fed's procedure could lead to exchange rate fluctuations sufficiently large to compromise the movement toward Monetary Union. A policymaker in Europe attempting to reduce the actual unemployment rate in response to a lower natural unemployment rate (achieved by a successful nicroeconomic reform policy) would notice first that inflation is turning out to be below forecast, and would react by reducing interest rates to stimulate the domestic economy in order to push down the actual unemployment rate. The cuntral aspect of this policy is taking the good news on inflation to be a signal that stimulative policies should be adopted to reduce the unemployment rate, rather than just "accommodating" the lower inflation rate by maintaining the existing unemployment rate.

\subsection{Structural Reform and Productlvity Growth}

The analysis of Figur: 13 did not take into account any effect of structural reform on the growth rate of potential output, which would reduce $x$ (the excess of 
nominal GDP growth over potential output growth) if actual nominal GDP growth were to remain unchanged. Uncertainty regarding the effect of structural reform on potential output growth stems from the conflict between two forces. Pure efficiency gains should raise productivity growth. But reforms in labor markets that make labor less expensive for employers to hire, such as the reduction or elimination of the minimum wage, may raise the demand for labor at a given level of output and reduce productivity. The same effect would be expected of particular product market reforms, especially a loosening of German regulations on shop-closing hours that would trade consumer convenience for an increase in the labor requirements needed to achieve a given total of real retail sales.

The interactions between changes in the degree of structural maladjustment, both in an adverse and beneficial direction, are explored in Gordon (1995b). The evolution of European unemployment is portrayed as resulting from a set of adverse wage-setting shocks (e.g., an increase in the real effective minimum wage) which initially raises unemployment and, by shifting the economy northwest up a labor demand curve, also boosts the marginal and average products of labor. This is then followed by a profit squeeze and a period of disinvestment, which eliminates the productivity gain but further increases the unemployment rate. Reversing this process by achieving a beneficial wage-setting shock (e.g., a reduction in the real effective minimum wage) would initially reduce unemployment and both the marginal and 
average products of labor. This would then be followed by a profits boom and an increase of investment, which would offset the initial productivity loss and further reduce the unemployment rate.

\section{Feedback from Macro Policy to Structural Reform and Vice Versa}

The analysis of Figure 13 emphasizes the opportunity for macro policy to respond to a reduction in the natural rate of unemployment achieved by structural reform. A policy response that stabilizes inflation and responds to a reduction in the natural rate as an opportunity to accelerate nominal demand growth differs from a passive policy in which excess nominal GDP growth $(x)$ is stabilized.

This policy choice may influence the likelihood and magnitude of structural reform. When there is strong political opposition to such reform measures as reducing the minimum wage and reducing government subsidies, the willingness of central bankers and finance ministers to respond aggressively to successful reforms may make those reforms more likely. There is potential for a political deal in which the demand-management authorities promise to lean toward lower interest rates and faster nominal demand growth, in trade for the willingness of political interest groups to support those reform measures that appear to have the greatest chance of reducing the natural unemployment rate. Demand expansion, by creating jobs, may also reduce the transition costs of reform policies which create temporary unemployment through the required restructuring of a particular industry that, for instance, has been 
overstaffed as a result of previous state ownership and subsidies (the "olive-belt" airlines come to mind).

Another related feedback is from monetary policy to fiscal policy. Demand expansion which reduces the unemployment gap brings the actual government budget deficit closer to the structural deficits displayed in Figure 5. A successful deal in which demand expansion goes hand in hand with structural reform may succeed in reducing the natural rate of unemployment and hence the structural deficits themselves. Reducing the deficit then raises the potential for using the fiscal dividend to reduce tax rates and hence the tax wedge, at least in those countries which are not on an explosive track for the debt-GDP ratio.

There is feedback in the reverse direction as well. Countries with more flexible labor markets may have a more favorable inflation-unemployment tradeoff, i.e., a flatter $S P$ schedule in Figures 10-13. This is particularly important from the perspective of the hysteresis hypothesis, which implies that a reduction in unemployment may be achieved at the cost of only a finite increase in the inflation rate, the amount of which depends on the slope of the short-run tradeoff curve. The United States, with its flexible labor market, has a very flat short-run tradeoff. Current estimates show that a one-year sustained reduction of the actual unemployment rate by one full percentage point below the natural unemployment 
rate raises the inflation rate by only 0.35 of a percentage point after one year (Gordon, 1995a, Table 1).

\section{Policy Lessons from the 1992-93 ERM Breakdown}

An important controlled experiment was carried out in Europe in 1992-93 when several important countries, particularly Italy, Portugal, Spain, Sweden, and the United Kingdom, broke away from the ERM and achieved substantial depreciations of their currencies against the countries which remained aligned with the Deutsche mark, including France, the Low Countries, Austria, and Switzerland. Some European analysts have previously believed that depreciation by any individual country is futile, since any transitory output gains soon would be eroded by an acceleration of inflation that will soon cause the competitive gains from the exchange depreciation to evaporate. In its most extreme form, this view holds that countries do not have any control, pest a transition period of a year or two, over their real exchange rates.

A pessimistic interprotation of the outcome of the 1992-93 divergence is provided by some authors. I)eGrauwe (1995, p. 9) focusses on the two cases of Italy and Spain. He points to the temporary nature of the competitive gains. While initially the sharp depreciations "did not affect inflation very much in these countries (mainly because of the rece:sion), since 1994 inflation differentials with Germany 
have started to increase significantly." He concludes that in order for Italy and Spain to guide their inflation rates to the differential prescribed by the Maastricht Treaty, a new policy of "painful disinflation" would have to begin. Since he views the prospect of success of such policies as low, he thinks that "the door to monetary union will be shut for a long time for these countries."

DeGrauwe's treatment is misleading, for numerous reasons. He focusses only on two depreciating countries. He greatly exaggerates the acceleration of inflation in those countries by comparing their inflation rates only with Germany, failing to note that the German inflation rate was temporarily high in 1992-93 as a result of the aftermath of the reunification boom. A more balanced appraisal would look at a set of countries that depreciated and compare them with a set of countries other than Germany that did not depreciate. The omission of Germany is crucial, because the time path of its disinflation in 1994-95 makes the inflation differential of any other country with Germany a misleading indicator of the inflation differential of that country with all countries other than Germany.

The results of the analysis are summarized in Table 2 . The five appreciating countries (not including Germany) are Austria, Belgium, France, Netherlands, and Switzerland. On average these countries experienced a nominal effective appreciation of 10.2 percentage points, from exchange rate indexes of 99.5 in 1992:Q2 to 109.7 in $1995:$ Q2. In contrast the depreciating countries - Italy, Portugal, Spain, Sweden, 
and the United Kingdom - experienced an average depreciation of 22.2 points, from an average index value of 99.1 in $1992: Q 2$ to 76.9 in $1995: Q 2$. All of the average values in Table 2 are weighted across the five countries in each group using SummersHeston 1985 PPP weights. Thus among the appreciating countries, the weight of France is 59 percent. Among the depreciating countries, the respective weights of Italy, Spain, and the U. K. are $36.2,17.0$, and 37.2 percent.

Both groups of countries enjoyed an acceleration of nominal GDP growth, a deceleration of inflation, and thus an even greater acceleration of real GDP growth. But there the similarity stops. The acceleration of nominal GDP growth in the depreciating countries exceeded that in the appreciating countries by 1.3 percentage points. Yet none of this was absorbed by inflation; inflation actually decelerated more in the depreciating countries than the appreciating countries. And as a result the acceleration of real GDP growth in the depreciating countries exceeded that in the depreciating countries by 1.7 percentage points.

It is implausible that this favorable outcome for the depreciating countries could continue forever, but the IMF forecasts for 1996 (from the same source as used for Table 2) show no acceleration of inflation to be predicted for the same average of five depreciating countries. Thus it appears that the depreciating countries have discovered a "macroeconomic free lunch," an improvement in competitiveness and a route to macroeconomic expansion without inflation. The implication is that there 
is substantial room for individual nations in Europe to reduce their unemployment gaps and their actual budget deficits through expansionary monetary policy. The inevitable depreciation in the nominal exchange rate will translate into a durable depreciation in the real exchange rate and an improvement in competitiveness.

With inflation in Germany at only 2 percent, some of which doubtless reflects the well-known upward bias in price indexes, there is ample room for Germany to lead the remaining nations tied to its exchange rate into a further expansion of nominal GDP growth. The experience of the depreciating nations suggests that the "split" of additional nominal GDP growth between output growth and inflation is highly favorable under present conditions. Stated another way, the benign behavior of inflation in Europe suggests that the natural rate of unemployment has begun to decline, just as the Federal Reserve believes has occurred within the United States. 


\section{Conclusion}

The management of demand policy interacts with structural maladjustment, both when maladjustment is getting worse, as in the 1970 s and early 1980 s, and when successful structural reforms reduce the influence of structural maladjustment and allow a decrease in the natural (i.e., constant-inflation) rate of unemployment. In our interpretation a combination of structural factors, rather than a single "silver bullet", explains the substantial increase in Europe's natural unemployment during the decade $1975-85$ and the divergence of that natural rate from the stationary or even declining natural rate in the United States. In the 1970s two supply shocks, in the form of higher real oil prices and an increase in labor's share in national income, pushed European economies in the direction of higher inflation and higher unemployment. Reactions of central banks varied, with monetary accommodation in some countries - but not others - leading to a substantial divergence of inflation rates in Europe by the early 1980 s.

These two supply shocks, both of which were temporary and had their influence reversed in the mid-1980s, combined with more deeply entrenched structural maladjustments to boost the European natural unemployment rate from low single digits in the early 1970 s to nearly 10 percent by 1985 . While real oil prices and labor's income share declined subsequently, the natural rate did not. This reflects the role of other longer-lasting maladjustments, especially inflexible real 
wages for the unskilled who were harmed by skill-biased technical change, and this inflexibility in turn reflects three dimensions along which Europe (on average if not for every country) differs from the United States - high and rising tax wedges, more powerful unions, and a higher and (in some countries) rising real minimum wage.

This account does not place much emphasis on hysteresis. Empirical research does not support the "pure hysteresis" view that requires the absence of level effects of the unemployment gap in dynamic wage and price adjustment equations. The most plausible channel by which hysteresis operated was through feedback from the other sources of maladjustment to low capital accumulation, with the result that the capacity utilization rate in Europe has been roughly stationary despite the rise in the natural unemployment rate. Stated differently, Europe no longer has sufficient capital to employ fully its existing labor force.

The paper stresses two-way interactions between structural reform and macro policy. With flexible labor markets, the short-run inflation-unemployment tradeoff is likely to be favorable, providing an incentive for policymakers to expand aggregate demand. The benign effect of the British depreciation in 1992 on the inflation rate provides one example of the potential payoff of more flexible labor markets. In turn, the promise by policymakers that they will encourage a decline in unemployment in response to good news on inflation can be used to strike a political deal with political interests opposed to the introduction or extension of structural reform. Expansionary 
monetary policy also provides relief on the fiscal front, both by reducing the unemployment gap and bringing the actual budget deficit closer to the structural budget deficit, but also, by encouraging structural reform, potentially reducing the natural unemployment rate and therefore the structural budget deficit itself.

In 1992-93 several European countries dropped out of the ERM to pursue more expansionary monetary policies. The difference in the performance of these countries and those countries which maintained a peg between their currencies and the Deutsche mark provides an important test case of the consequences of expansionary monetary policy. Not surprisingly, the depreciating nations by 1995 enjoyed a substantial acceleration of nominal GDP growth relative to the nations that did not depreciate. But, surprisingly, they enjoyed an even greater deceleration of inflation, so that their growth rate of real GDP accelerated more than their growth rate of nominal GDP.

This augurs well for a favorable outcome of expansionary demand policy. It may be that the natural unemployment rate has begun to decline significantly in Europe, and that this explains why inflation has continued to decelerate in countries which have depreciated their exchange rates significantly. Job creation in those countries creates an environment favorable to continued success in structural reform.

The set of issues addressed in this paper seems a long way from the depressing litany of contractionary demand decisions currently being made in numerous 
European countries in the name of the Maastricht criteria. Some countries are on an explosive path for the debt-GDP ratio and need to bring their fiscal house in order. An important lesson can be drawn from the traditional textbook discussion of the fiscal-monetary mix, that a shift toward tighter fiscal policy need not reduce output or raise unemployment if accompanied by a shift toward easier monetary policy. A shift toward a mix of tighter fiscal policy and easier monetary policy can occur in two ways. First, the Bundesbank could adopt easier policies, allowing other countries to expand while maintaining a fixed exchange rate with Germany. Second, if the Bundesbank does not adopt easier policies, other countries have the option of abandoning the path to monetary union and adopting expansionary monetary policies that would bring down both the actual and natural rates of unemployment with a minimal acceleration of inflation. 


\section{REFERENCES}

BeAN, Charles R. (1994). "European Unemployment: A Survey," Journal of Economic Literature, 32 (June), 573-619.

BRANSON, WILLIAM H. AND ROTEMBERG, JULIO J. (1980). "International Adjustment with Wage rigidity," European Economic Review, 13 (May), pp. 309-32.

BRUNO, Michael, AND SACHS, JefFrey D. (1985). Economics of Worldwide Stagflation (Cambridge MA: Harvard University Press).

CROSS, ROD (ED.) (1988). Unemployment, Hysteresis, and the Natural Rate Hypothesis. Oxford and New York: Basil Blackwell.

(1995a). The Natural Rate of Unemployment: Reflections on 25 Years of the Hypothesis. (Cambridge UK: Cambridge University Press). (1995b). "Is the Natural Rate Hypothesis Consistent with Hysteresis?" in Cross, ed. (1995a), pp. 181-200.

DeGraUWE, PAUL (1995). "The Economics of Convergence towards Monetary Union in Europe," CEPR discussion paper 1213, July.

Elmeskov, JørGen, AND MacFarlan, MATtLand (1993). "Unemployment Persistence," OECD Economic Studies (no. 21, Winter), pp. 57-88. 
FranZ, Wolfgang, and Gordon, Robert J. (1993). "Wage and Price Dynamics in Germany and America: Differences and Common Themes," European Economic Review, 37 (May), pp. 719-54.

Giorno, Claude, Richardson, Pete, Roseveare, Deborah, and van den Noord, PAUL (1995). "Potential Output, Output Gaps, and Structural Budget Balances," OECD Economic Studies (no. 24), pp. 167-209.

GORDON, ROBERT J. (1995a). "Estimating the NAIRU as a Time-varying Parameter," paper presented to Panel of Economic Advisers, Congressional Budget Office, November 16. (1995b). "Is There a Tradeoff between Unemployment and Productivity Growth?" NBER working paper 5081, April. Forthcoming in Dennis J. Snower and Guillermo de la Dehesa, eds., Unemployment Policy: How Should Governments Respond to Unemployment? Cambridge UK: Cambridge University Press for CEPR.

Krugman, Paul (1994). "Past and Prospective Causes of High Unemployment," Federal Reserve Bank of Kansas City Economic Review (fourth quarter), pp. 2143.

LAYARD, Richard, Nicklell, StePHEN, AND JaCKMAN, RiCHARD (1991). Unemployment: Macroeconomic Performance and the Labor Market (Oxford: Oxford University Press). 
OECD (1994a). The OECD Jobs Study: Unemployment in the OECD Area, 195095. (Paris). (1994b). Assessing Structural Reform: Lessons for the Future. (Paris).

SACHS, JefFrey D. (1979). "Wages, Profits, and Macroeconomic Adjustment: A Comparative Study," Brookings Papers on Economic Activity, 10 (no. 2), pp. 269-319. 


\section{Table 1}

\section{Gaps between Actual and Structural Deficit/GDP Ratios and Deficit/GDP Ratio Required to Stabilize Debt/GDP Ratio, 1995, Selected Countries}

\begin{tabular}{|c|c|c|c|c|c|c|c|}
\hline & U. S. & France & U. $\mathbf{K}$. & Germany & Spain & Sweden & Italy \\
\hline 1. Debt-GDP Ratio & 46.0 & 51.5 & 52.5 & 58.8 & 64.8 & 81.4 & 124.9 \\
\hline $\begin{array}{l}\text { 2. Warranted Nominal } \\
\text { GDP Growth }\end{array}$ & 5.0 & 4.1 & 4.2 & 5.0 & 7.9 & 4.9 & 7.1 \\
\hline $\begin{array}{l}\text { 3. Stability Value of } \\
\text { Deficit/GDP Ratio }\end{array}$ & 2.3 & 2.1 & 2.2 & 2.9 & 5.1 & 4.0 & 8.9 \\
\hline 4. Actual Deficit & 1.8 & 5.0 & 4.7 & 2.4 & 6.1 & 10.2 & 7.8 \\
\hline $\begin{array}{l}\text { 5. Actual Deficit } \\
\text { minus Stability Value }\end{array}$ & -0.5 & 2.9 & 2.5 & -0.5 & 1.0 & 6.2 & -1.1 \\
\hline 6. Structural Deficit & 2.3 & 3.5 & 3.1 & 1.8 & 4.0 & 8.2 & 7.5 \\
\hline $\begin{array}{l}\text { 7. Structural Deficit } \\
\text { minus Stability Value }\end{array}$ & 0.0 & 1.4 & 0.9 & -1.1 & 1.1 & 4.2 & -1.4 \\
\hline
\end{tabular}

Source by line: $1 . \quad$ Figure 6.

2. 1995 Potential Output growth from Giomo et. al. (1995), Table 2, plus 1995 rate of change of GDP deflator, from IMF World Economic Outlook, October 1995, Table A-9.

3. Line 1 times line 2, calculated as percent.

4,6 Figure 5. 
Table 2

Change in Effective Exchange Rates, and Growth Rates of Nominal GDP, Real GDP, and GDP Deflator, 1992-95, Five Appreciating Countries and Five Depreciating Countries

\begin{tabular}{||lccc||}
\hline Effective Nominal & $\begin{array}{c}\text { Appreciating } \\
\text { Countries }\end{array}$ & $\begin{array}{c}\text { Depreciating } \\
\text { Countries }\end{array}$ & $\begin{array}{c}\text { Difference, } \\
\text { Depr - Apr }\end{array}$ \\
\hline Exchange Rate & & & \\
1992:Q2 & 99.5 & 99.1 & -0.4 \\
1995:Q2 & 109.7 & 76.9 & -32.8 \\
1995-1992 & 10.2 & -22.2 & -32.4 \\
Percent Change in & & & \\
Nominal GDP & & & \\
1992 & 4.2 & 5.0 & 0.8 \\
1995 & 4.6 & 6.7 & 2.1 \\
1995-1992 & 0.4 & 1.7 & 1.3 \\
Percent Change in & & & \\
Real GDP & & & -1.5 \\
1992 & 1.7 & 0.2 & 0.2 \\
1995 & 2.7 & 2.9 & 1.7 \\
1995-1992 & 1.0 & 2.7 & \\
Percent Change in & & & 2.3 \\
GDP Deflator & & & 1.9 \\
1992 & 2.5 & 4.8 & -0.4 \\
1995 & 1.9 & 3.8 & \\
1995-1992 & -0.6 & -1.0 & \\
\hline \hline
\end{tabular}

Source Notes: Appreciating countries are Austria, Belgium, France, Netherlands, Switzerland. Depreciating countries are Italy, Portugal, Spain, Sweden, and the United Kingdom.

All data are aggregated using 1985 Summers-Heston GDP weights.

Nominal and real GDP and GDP deflator growth rates are from IMF World Economic Outlook, October 1995, Tables A2 and A9. 


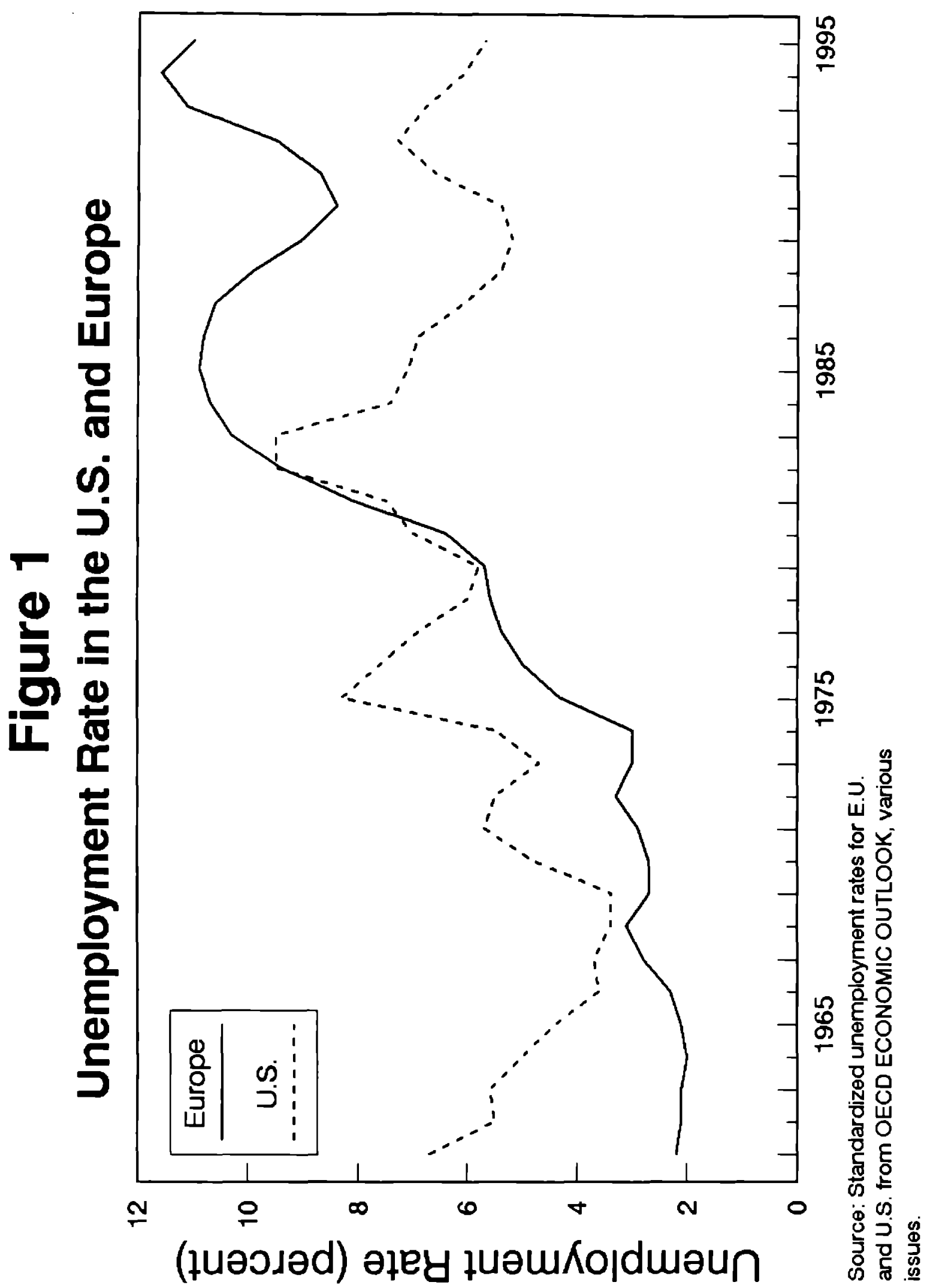




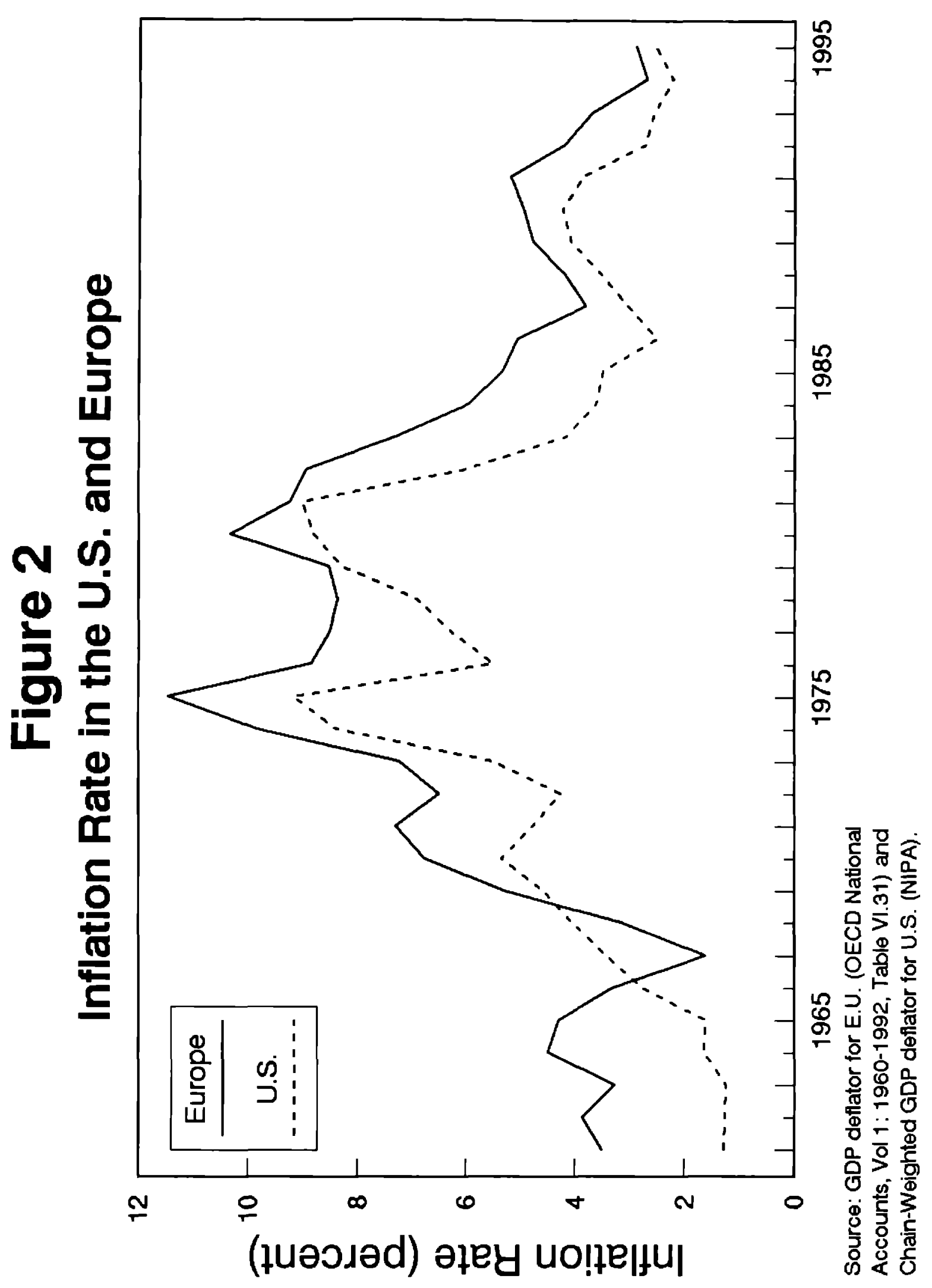




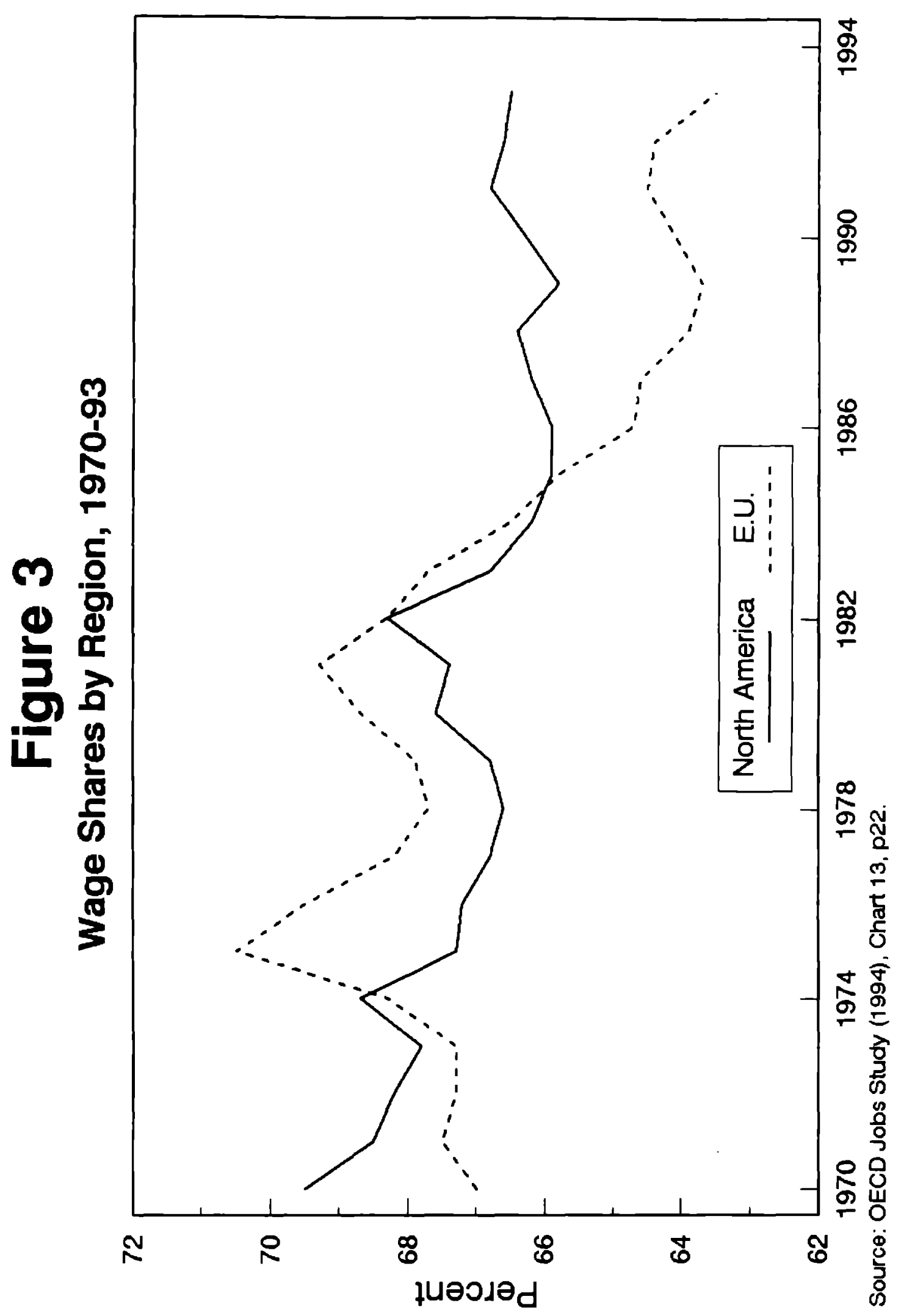




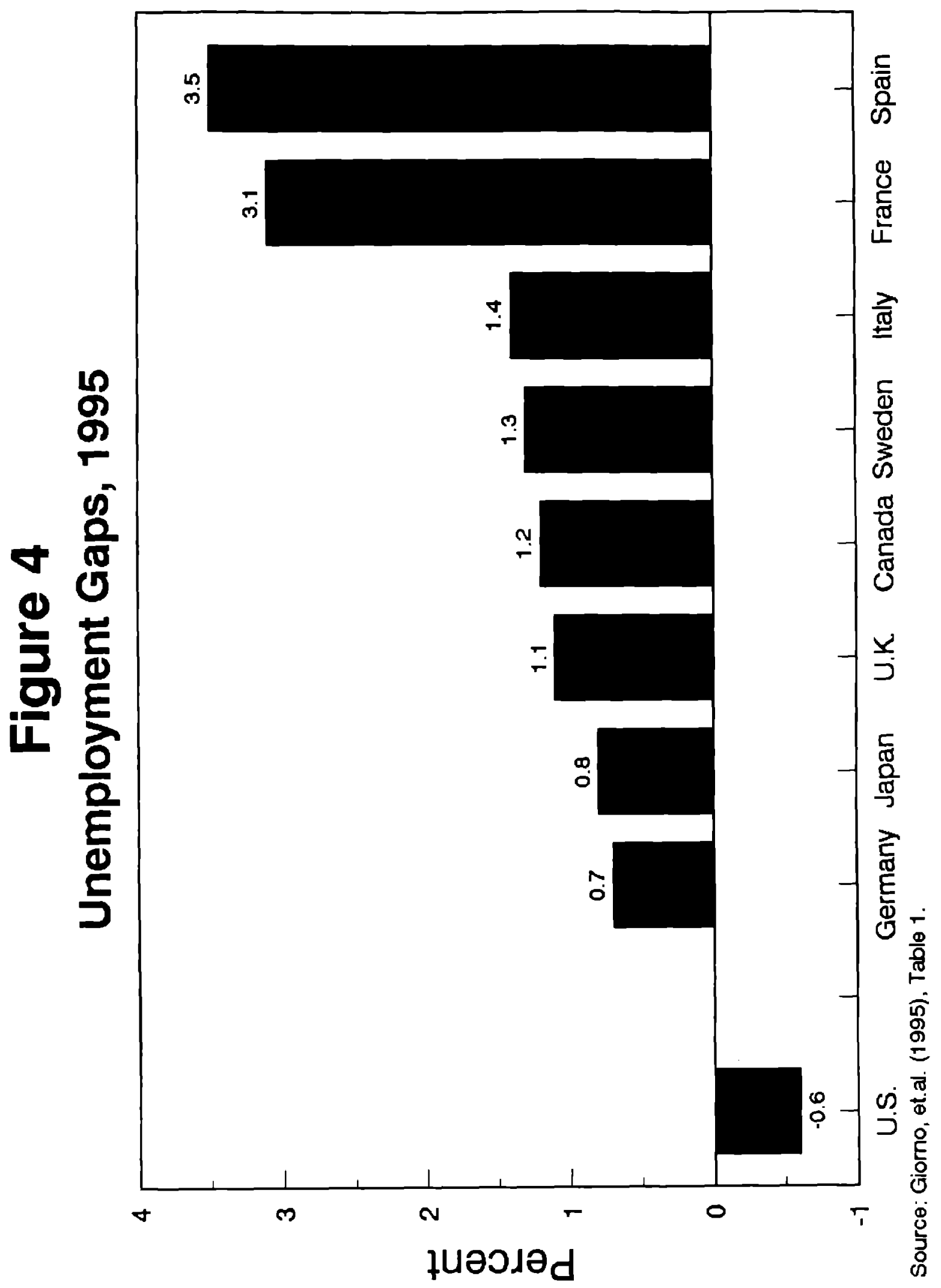




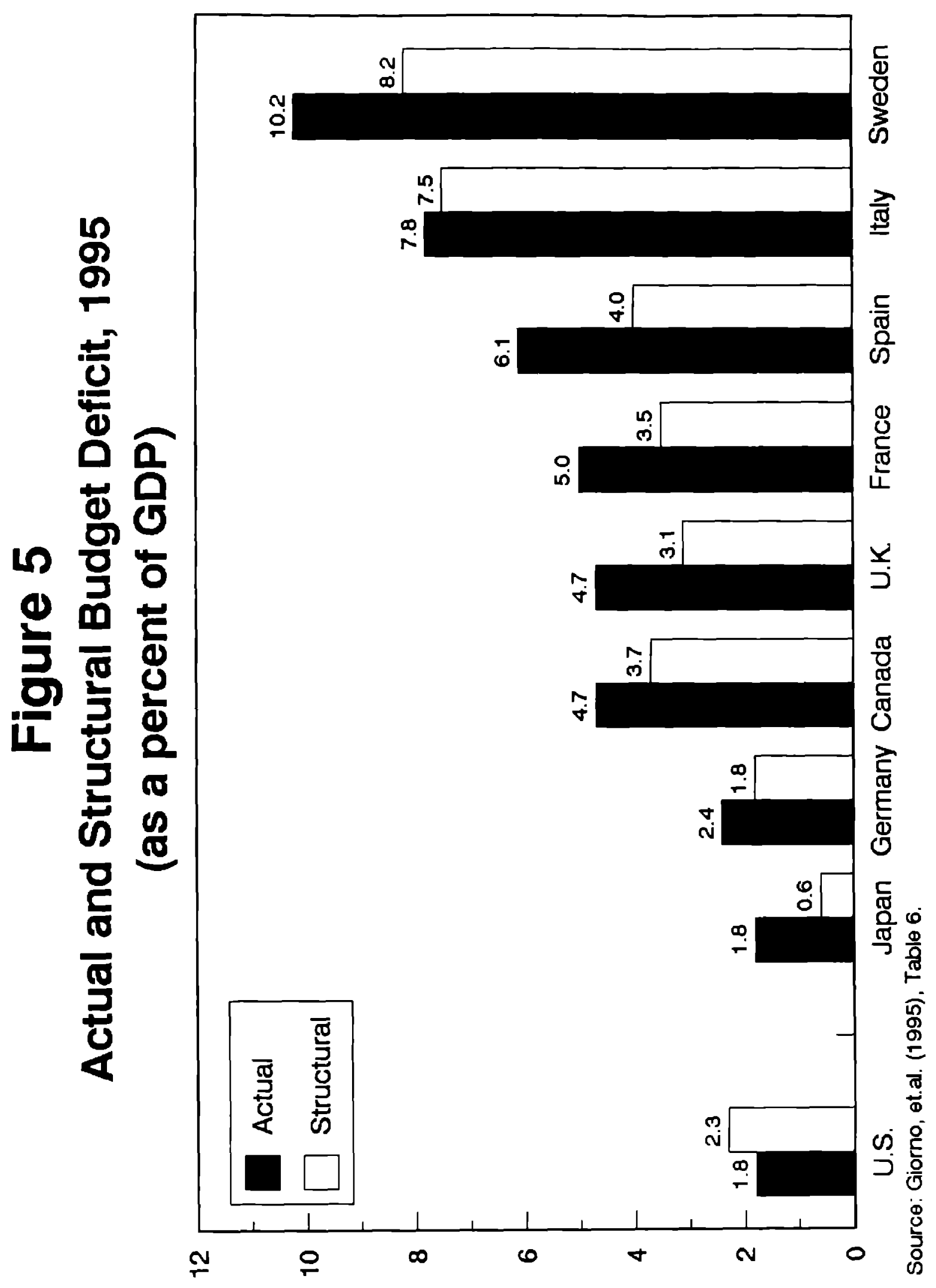




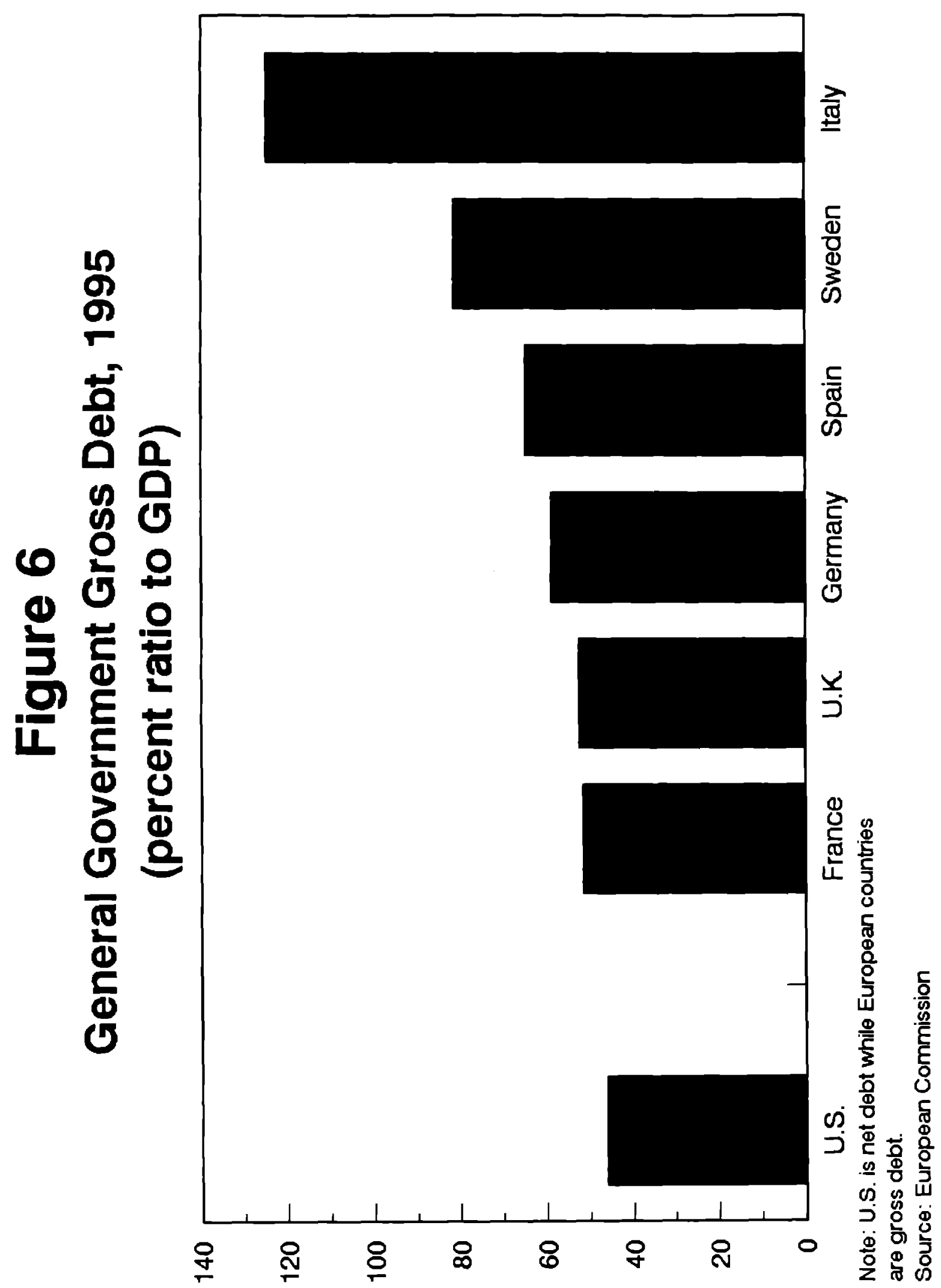




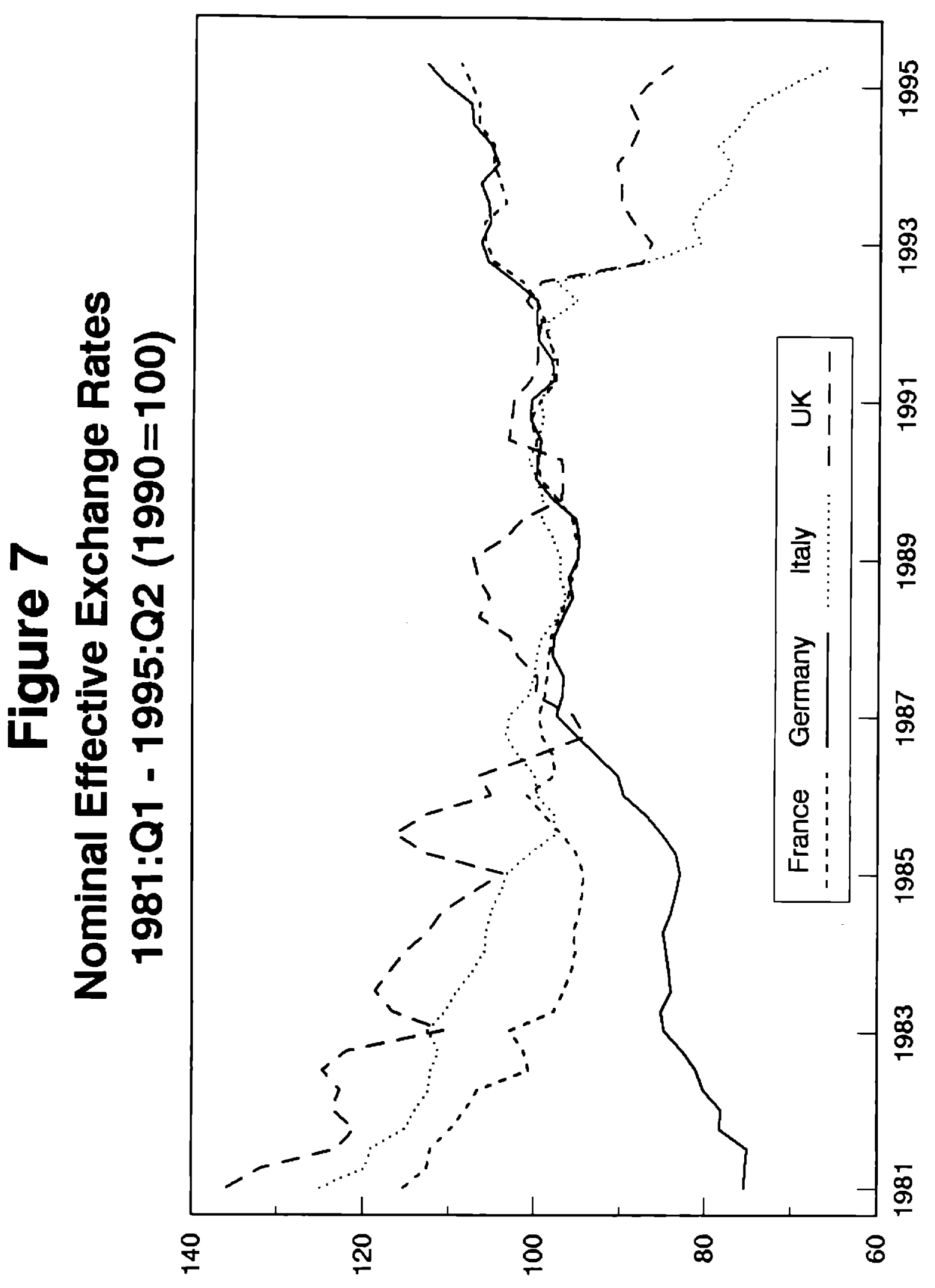




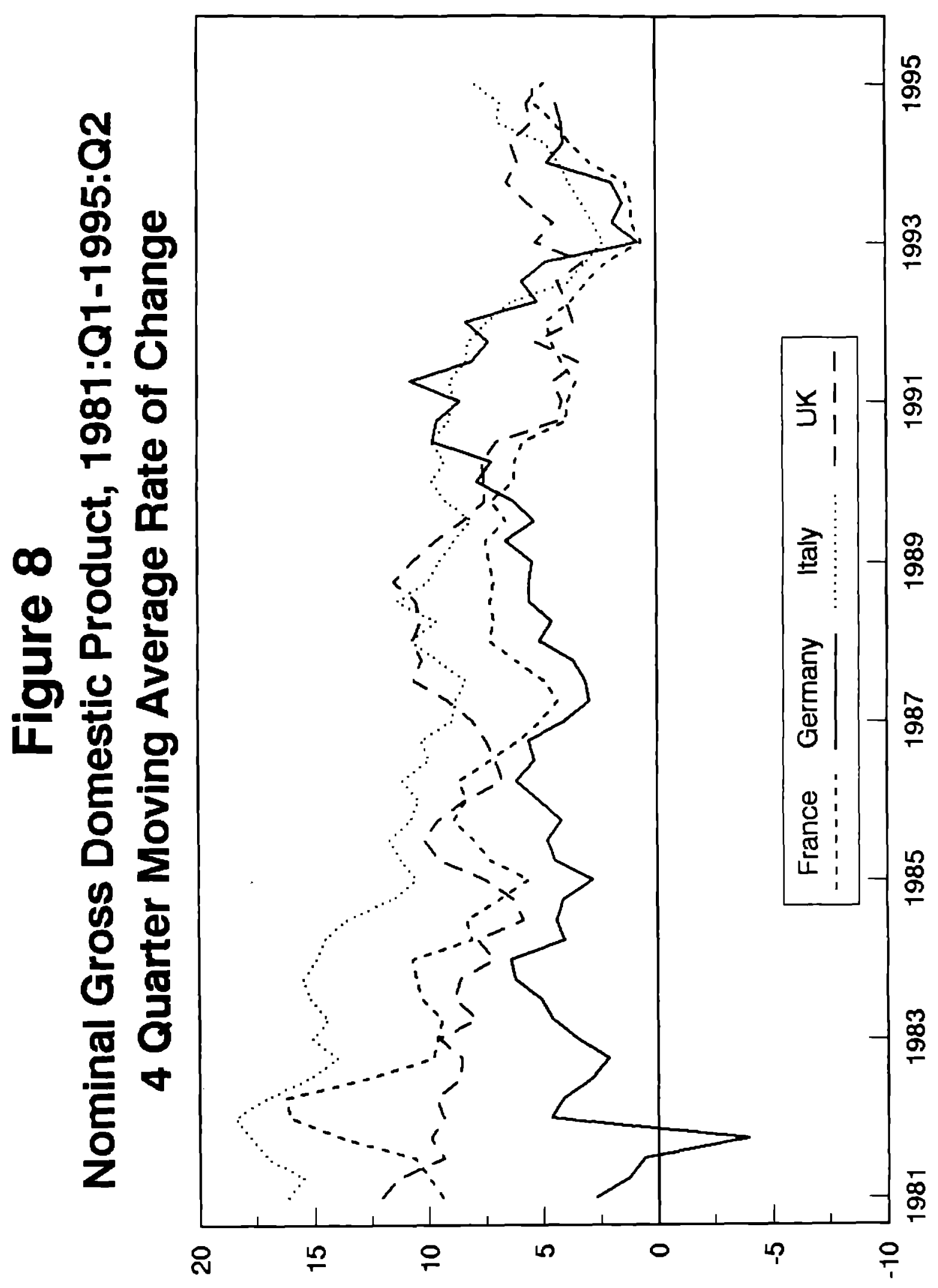




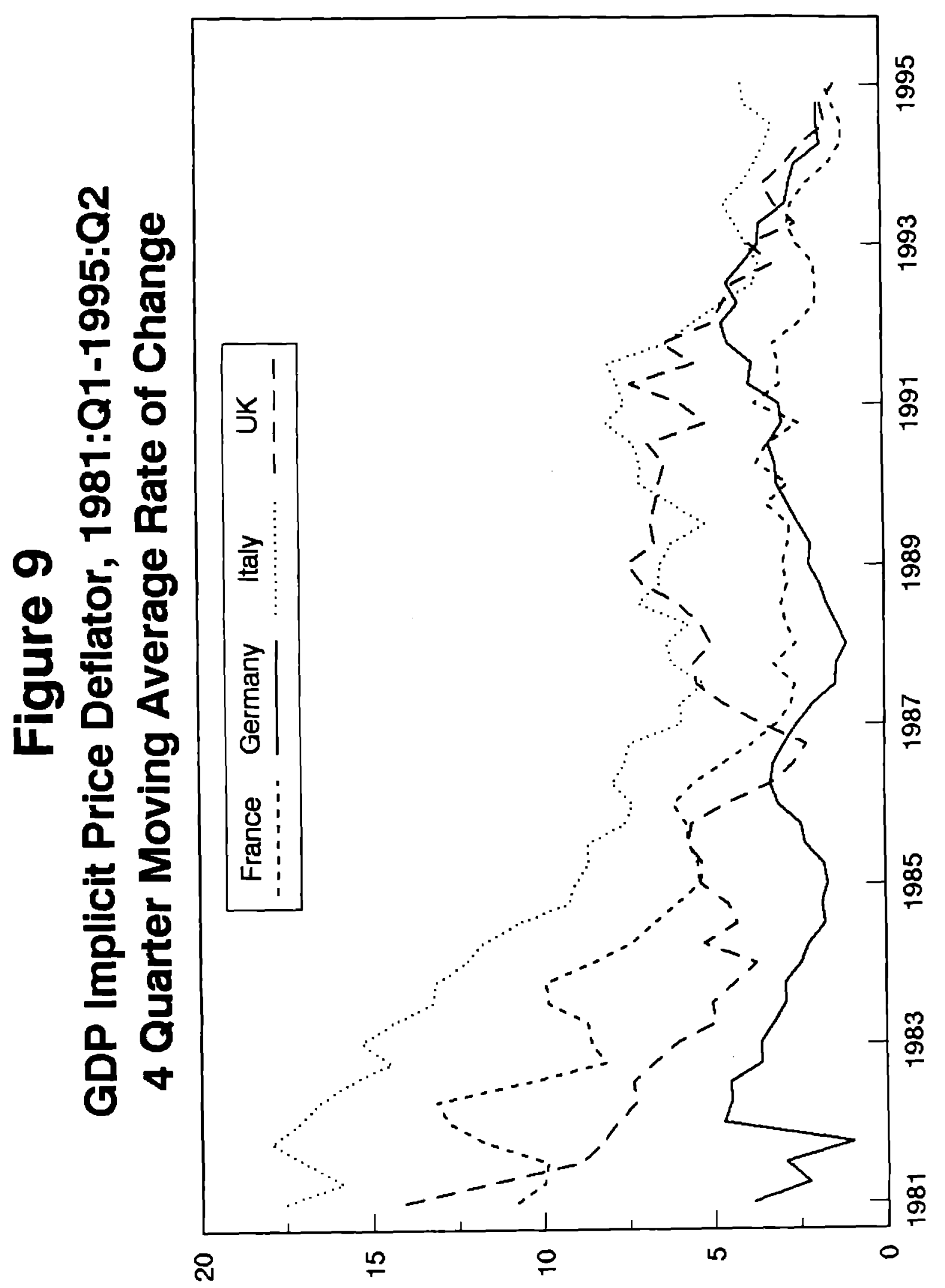




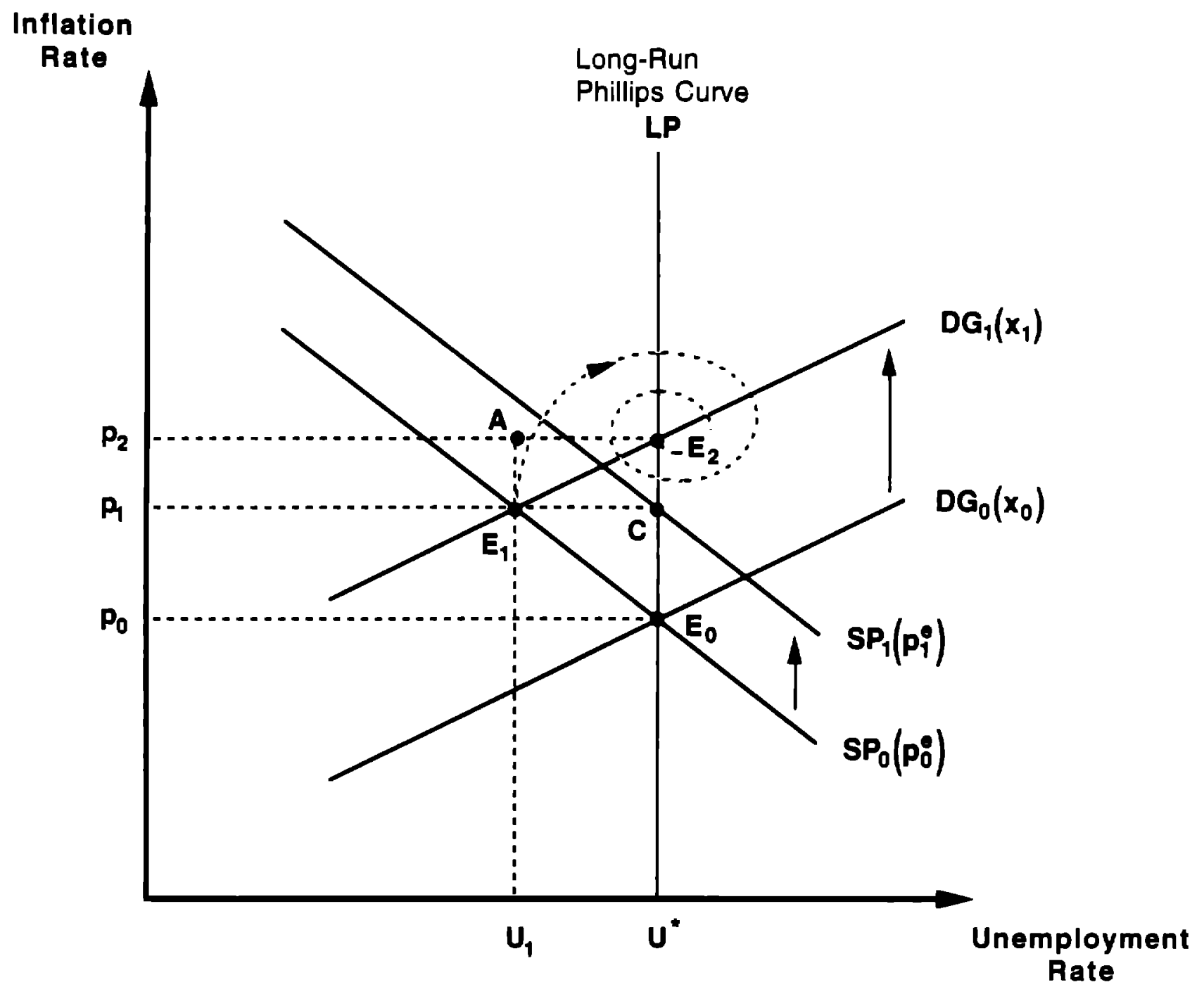

Figure 10 


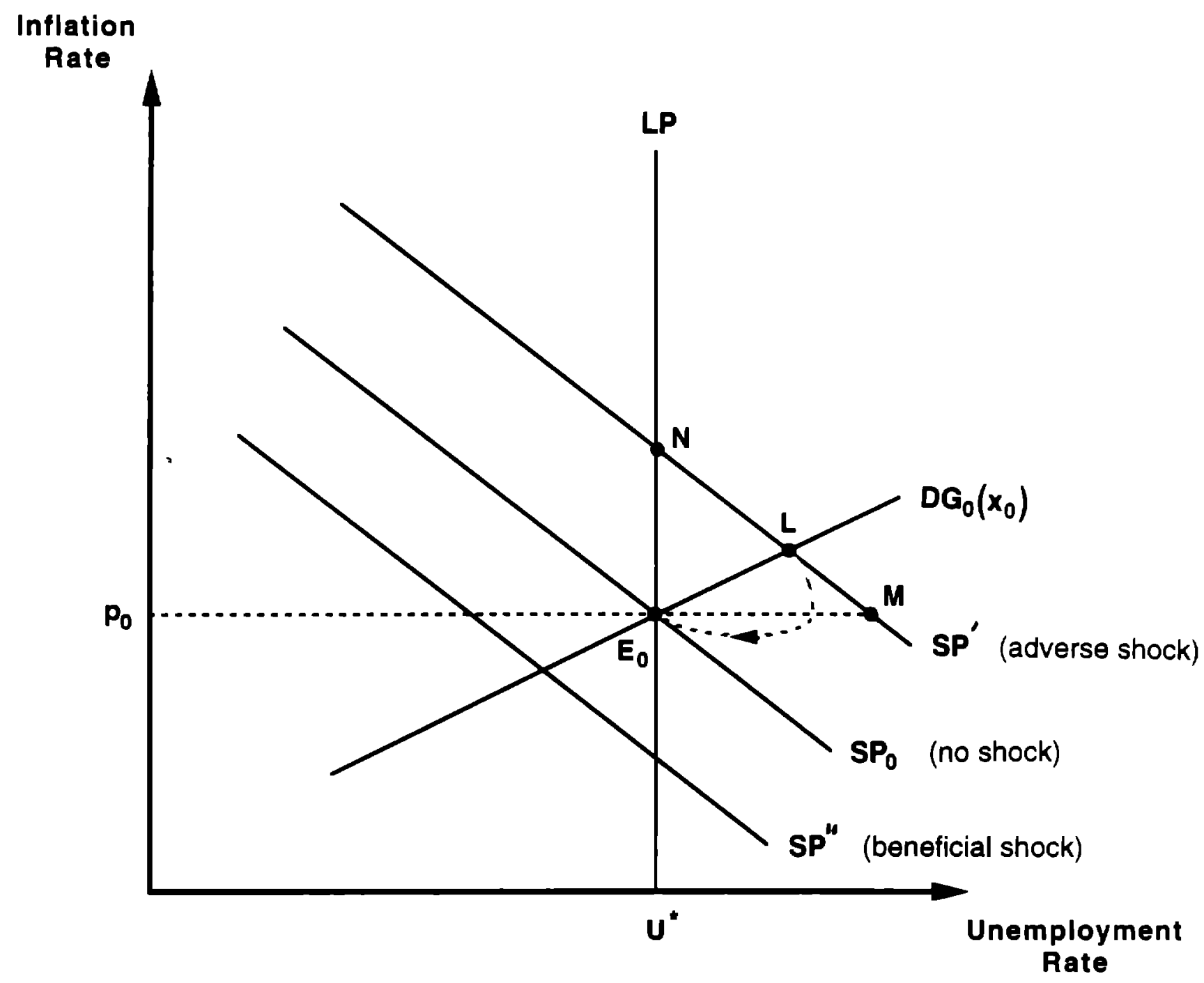

Figure 11 


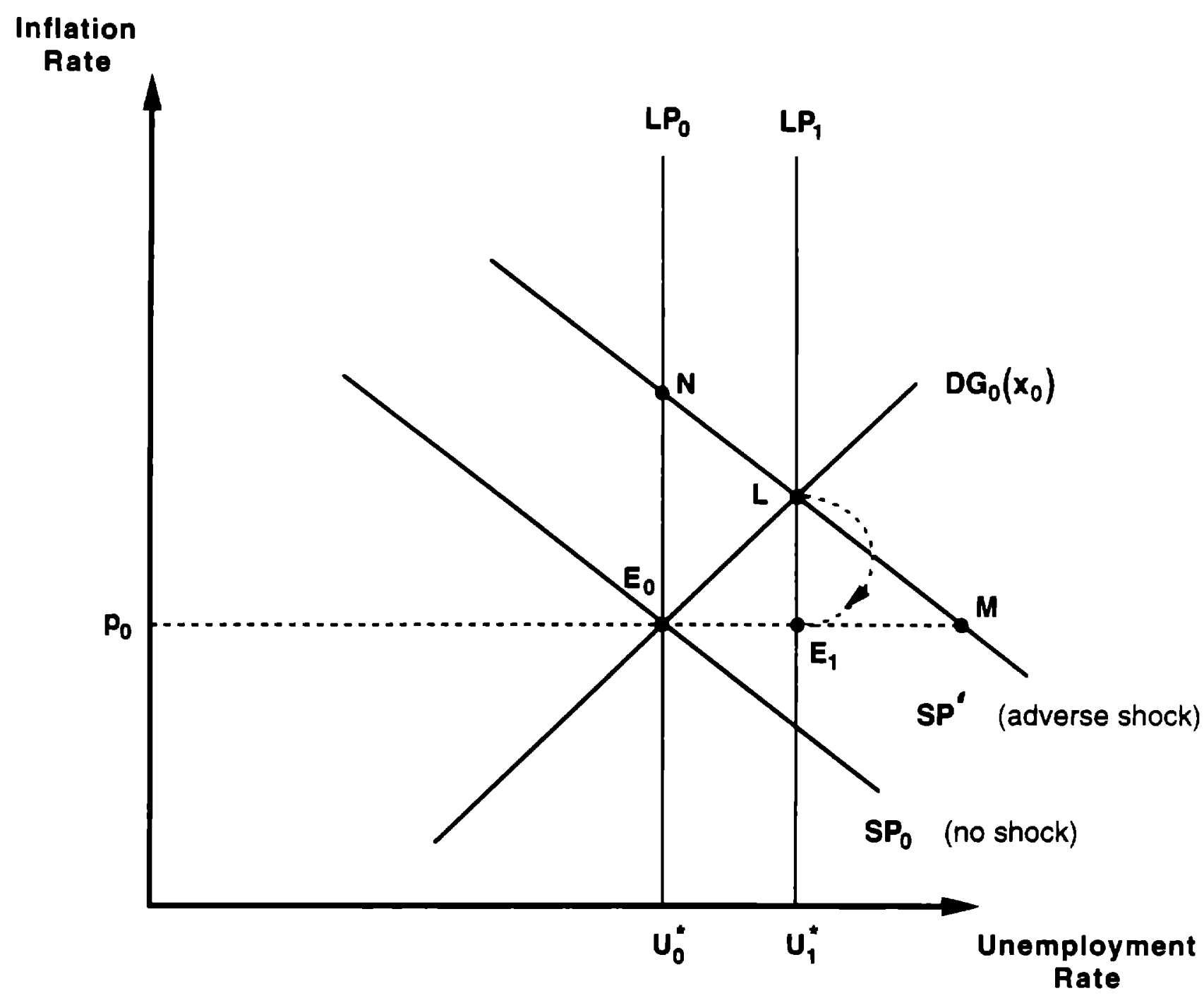

Figure 12 


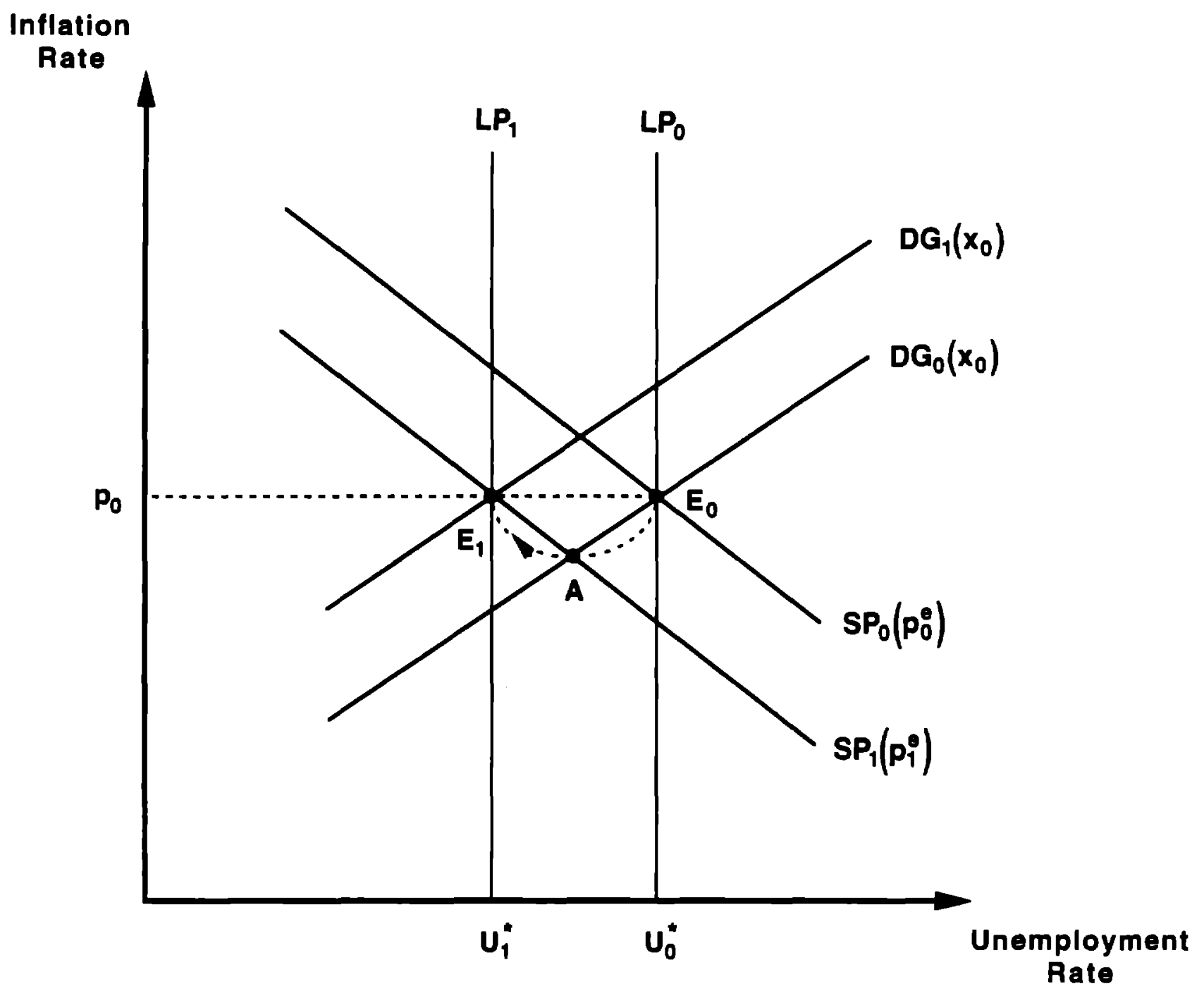

Figure 13 